\title{
A dynamic approach to localness in the context of conflict-affected internal displacement and return in Ukraine
}

\section{Svitlana Balinchenko ${ }^{1}$ (1)}

Received: 20 August 2020 / Accepted: 13 January 2021 / Published online: 15 February 2021

(C) The Author(s), under exclusive licence to Springer Nature Switzerland AG part of Springer Nature 2021

\begin{abstract}
In the article, the special aspects shaping the choice of internally displaced persons to integrate into a host community or return to the former place of residence are viewed in the context of protracted internal displacement triggered by Russia-backed armed conflict in eastern Ukraine. Due to the inaccessibility of the reliable data on the population of the temporarily occupied regions of Donetsk and Luhansk oblasts of Ukraine, the data on internally displaced persons and returnees from the sample of International Organization for Migration, 2018-2020, have been used to study the contexts of adaptation and return, such as reasons to integrate or go back to an unsafe environment. The author suggests an application of refrain (after Deleuzian ritournelle), as a unity of the aspects of chaos, abode, and escape, to the situation of internal displacement. The key observations make it possible to suggest that forming and change of localness imply either the ritournelle missed as a disrupted adaptation and return, or the ritournelle achieved when displaced newcomers become new locals in the host communities. Thus, localness is regarded as a dynamic characteristic that can be boosted or reshaped through treating the displaced persons as equals, in terms of benefits and burdens distribution, providing access to decision-making, and promoting the sense of belonging to a community. The study is also aimed at formulating the questions for future investigations of the group of returnees, and thus shaping the criteria for the assessment of future durable solutions and reintegration scenarios.
\end{abstract}

Keywords Ukraine - Protracted internal displacement - Internally displaced person · Returnee $\cdot$ Right to treatment as an equal $\cdot$ Adaptation

Svitlana Balinchenko

sp.balinchenko@gmail.com

1 Yuriy Fedkovych Chernivtsi National University, Chernivtsi, Ukraine 


\section{Introduction}

According to the July 2020 report of the International Organization for Migration (IOM), there have been registered 1,450,798 internally displaced persons (IDPs) in Ukraine (IOM 2020, p. 1). The massive protracted internal displacement of the population is conflict-related. Since 2014, it has been caused by the ongoing Russia-inflicted war in eastern Ukraine and the annexation of Crimea by the Russian Federation. The war is defined as a hybrid or network warfare (Bocharnikov and Sveshnikov 2017; Dodonov et al. 2017; Levchenko 2017; Morris 2015; Van Metre 2017) and characterized by information distortions and anti-Ukrainian impacts. Therefore, the surveys on migration, internal displacement, and return of citizens to the temporarily occupied territories mostly lack reliable data on the population of the non-government-controlled areas of Donetsk and Luhansk oblasts of Ukraine (the NGCA).

The National Monitoring System Reports on the Situation of Internally Displaced Persons, issued by IOM Ukraine (thereinafter-NMS Reports), demonstrate that about $18-20 \%$ of the informants having taken part in the rounds of interviews are returnees to the NGCA (National 2019b, p. 48). The decision to return usually follows the displacement and some failed attempts to get adapted to the communities in the government-controlled areas of Ukraine. The study of the aspects behind the IDPs' decision to return to the now-occupied place of residence, in the situation of conflict-triggered displacement, is high in topicality for Ukraine nowadays, especially in the view of tailoring the durable solutions and policies for the phases of the conflict de-escalation and further reintegration of the factious communities.

In the paper, the focus is laid on the IDPs- and returnees-associated tendencies in Ukraine, associated with the IDPs' choice between integration into the host community and return to the former one. The challenges of integration, return, and reintegration of returnees into the former community under the new circumstances, have been viewed through safety, discrimination, and dependency factors, as well as equality-related issues. The data reflected in the paper appeared sporadically in the national and regional reviews, reports, and surveys on conflict-related migrations and interactions of the population. For instance, the study-relevant data on IDPs and returnees in Ukraine have been viewed through Rounds $12-15$ of the NMS Reports, based on the interviews collected by IOM from December 2018 through June 2019 in the government-controlled regions of Ukraine. One of the reasons for choosing the secondary quantitative analysis of this kind as a key method lies in research inaccessibility of the population of the occupied regions of Ukraine, in the context of factiousness and armed combat. Thus, the information provided by the former IDPs in IOM interviews, after them having returned to the occupied territories, makes it possible to reveal the intentions and circumstances relevant for studying the localness transformation.

The problem statement. In Ukraine, approximately one in five IDPs decides to return to the NGCA, thus preferring instable militarized self-proclaimed "republics" to the official state, regardless of the safety issues associated with the armed 
combat, as well as experience of adaptation failure, and the possibility of a biased attitude of those who did not leave the occupied territory. Thus, there is a need for evaluation of the coping mechanisms and their failures that lead to the return choice. The problem requires to be investigated, with due attention paid to the individual and community-based factors that make the internal displacement disrupted before the conflict is resolved and the initial reason for the relocation is eliminated.

Therefore, both in the Ukrainian context and wider, there is also the perspective of a better understanding of the factors that define social cohesion or a split in conflictaffected communities. The primary research question can be formulated as follows: What are the coping mechanisms that define for an IDP the choice between a return to the former place of residence and integration into the current community? Among the subquestions, the important ones are on the contexts shaping the motivation of returnees: To what extent does perception of the displacement as temporary or permanent influence the decision of an IDP to return or integrate? What is the role of reliance on locals, family, and authorities in making the choice to return? To what extent does the sense of belonging to the place and nostalgia influence the individual coping mechanisms during internal displacement? These aspects are mostly represented in the interview data of the above-mentioned IOM surveys in Ukraine. The equality issues have been viewed through the subquestion as follows: Is equality of IDPs in a host community achievable in the context of de facto limited access to decision-making, exclusive control measures, and difficulties in benefits distribution? In the perspective of durable solutions, another key subquestion is the following: How can returnees' experience of failed integration be considered in displacement-related legislation, as well as postconflict reintegration scenarios?

In the recent literature and reports on returnees in other countries, there have been covered the issues referring to the reintegration challenges and community-related factors that affected return refugees (Report on a Reintegration 2019; Digidiki and Bhabha 2019), and IDPs-returnees moving to relatively safe areas after partial de-escalation of a conflict (IOM Nigeria 2017; DTM Nigeria 2020). In the view of novelty, the paper addresses the issues related to the reasons, short-term and long-term outcomes of IDPs' return to the currently occupied territories in the situation of conflict-related protracted displacement. The highlights of the study include (1) individual evaluation of return and integration options by IDPs, as reflected in the surveys; (2) the equality issues arising during interactions of IDPs and host communities and having an impact on integration processes; and (3) the possible impact of disrupted adaptation on post-conflict regulation strategies. Thus, the investigation of the above-mentioned questions can help to study the gap in integration processes and therefore have an impact on the formation of durable solutions and policies based on social cohesion estimation and promotion.

\section{Materials and methods}

Due to the occupation of some areas of Ukraine, such as Crimea, by the Russian Federation, and the areas of Donetsk and Luhansk oblasts-by Russia-backed selfproclaimed republics, these conflict-affected regions are mostly inaccessible for 
surveys and public opinion polls. There are numerous security risks and fieldwork constraints that prevent getting the full scope of data on the population of the occupied territories. In 2020 Report Toward a Common Future: Voices from both Sides of the "Contact Line", among the constraints, there have been mentioned the following ones: the absence of reliable data on demographic changes, security risks for enumerators and interviewees due to suspiciousness of the population to the strangers in the conflict-affected communities, as well as problematic data quality assurance (Toward 2020, p. 15). For instance, the information on the NGCA residents for the 2019 USAID Report was collected by an anonymous polling company, using a face-to-face snowball technique (Ibidem, p. 14). Another recent report on the population of the Eastern Conflict Area, as of April 2020, refers to the data of the IOM Returnee Express Survey (Impact of COVID-19 2020). The survey was conducted via phone, and the returnees' sample was drawn from the IDP registration database of the Ministry of Social Policy of Ukraine, as well as based on the research data from NMS reports (Impact of COVID-19 2020, p. 1). The methodology of the survey is mentioned as based on convenience sampling, and there is marked in the report that "the results are only indicative of the surveyed population characteristics" (Ibidem).

Though it is not uncommon to use non-probability sampling strategies in empirical surveys with the participation of migrants, asylum seekers, refugees, and displaced persons (A Review of Empirical Surveys 2018; Sulaiman-Hill and Thompson 2011), the accumulated limitations arise from the inaccessibility of some groups of conflict-affected population and, therefore, restricted possibilities for the data to be assessed with due accuracy during the secondary quantitative analysis. The limitations relevant for the study include, on the one hand, the general abridgment associated with convenience sampling, for instance, such as lack of reliable data to make "a formal inductive inference concerning the population of interest" (Etikan et al. 2016). On the other hand, there are specific limitations of studying the data on returnees in the context of the ongoing war, as the group of population is especially vulnerable, under the conditions of the return to the occupied territories, as well as inhomogeneous both in the view of the triggers driving the persons to return and in the attitudes of returnees towards the official Ukrainian authorities and self-proclaimed republican ones. Nevertheless, the key assumption is that taking to account the limitations, the returnees might provide valuable information about the needs and motivation of the NGCA residents, and their attitudes towards displacement and reintegration. Hence, it is important to trace the tendencies based on the information of the returnees that had been registered as IDPs in the government-controlled areas of Ukraine (the GCA) at the moment of displacement, and then moved to the NGCA, but are still willing to participate in the interviews for the National Monitoring System Reports on migration and displacement.

In this article, in the course of the secondary analysis, mixed methods based on the qualitative and quantitative data on IDPs and returnees of the NMS Reports, 2018-2019, have been used in order to test the argument that the sense of belonging, reliance on locals, and equality issues have an impact on adaptation success or failure in the situation of conflict-triggered internal displacement. The data of other recent surveys and reports on Ukraine (Humanitarian Needs 2020; Impact of 
COVID-19 2020; Evaluation 2020; Toward 2020; Ukrainians Perceptions 2020), as well as the court cases (Case 2013; Decision 2018), and the legislative acts of Ukraine (The CMU Resolution 2014, 2019), based on the probability sample techniques of register- and location-based sampling, have been used to evaluate the actual challenges and develop the theoretical explanations of the possible causes and outcomes of the disrupted adaptation of IDPs in host communities. The research is longitudinal; the same question-related data of NMS Reports have been studied through Rounds 11-15. The action approach correlates with the tendency of involving academicians and researchers in discussions on the reports and survey results in Ukraine.

One of the reasons for the prognosis that the discussions and publications on the topic of localness transformations during the conflict-related internal displacement may have wider migration policy-forming and policy-changing potential is grounded on the rising interest in migration studies to an assessment of structural and direct injustice in the context of migration practices and policies.

For instance, Hillier-Smith (2020) evokes an interesting discussion on doing and allowing harm, in the Journal of Ethics and Social Philosophy, referring to migration-related norms in Europe and the conditions for their possible trial and justification. Hillier-Smith mentions a structural injustice in the situation of forced displacement, as understood after Parekh in terms of the injustice not being the result of a certain policy but rather some structural processes, and refuses to follow the position (Hillier-Smith 2020, pp. 299-300). Instead, the researcher suggests that state practices may imply direct harm, thus the migration reform requires not only assessment of the policies but the involvement of the relevant societal participants in the discourse on harm and aid:

I will thus simply assume the doctrine's moral significance in order to reach a normative assessment of state practices that could carry the widespread public agreement necessary to motivate potential reform. If these practices are indeed instances of doing harm, then, contra (italics - B. H.-S.) the dominant Duty of Rescue Approach, states that adopt them are not innocent bystanders, and are not merely failing to aid refugees, but are instead responding to their calls for aid by directly harming them (Hillier-Smith 2020, p. 300).

As for the Ukrainian context, the transformations of norms and state practices in Ukraine, in the context of conflict-affected population and migration-related challenges, may include assessment of the results of military disengagement since 2019 at the contact line with the occupied territories, in terms of doing and allowing harm. The state practice may not only affect the sense of belonging and localness perception of the population of the new "gray zone" emerging due to the disengagement but it also corresponds with the description of harm, after Hillier-Smith's assessment of harming state practices, as both locals and the persons displaced from the region are made "occupy a level of well-being that is worse than it would be in the nearest possible world in which that practice does not occur" (Hillier-Smith 2020, p. 302).

Thus, in 2019, the concerns having been expressed by the residents of the affected settlements were about "security, law and order, should the military leave," as well 
as about possible "displacement of professionals as a result of perceived insecurity" (The protection cluster 2019, p. 1). The public reaction to the military disengagement in the situation of ceasefire violations, in 2019-2020, took the form of "Stop capitulation!" and "Stop the recoup!" actions organized by a non-partisan civil movement against capitulation, Rukh proty Kapituliatsii. Nevertheless, the massive public critique of the governmental decisions appeared to lack effect on the state practice implementation: the military disengagement goes on in four more zones, as of November 2020 (Na Donbasi 2020), despite the OSCE observations of 13,977 ceasefire violations, high concentration of weapons in violation of the withdrawal line, and numerous freedom of movement restrictions registered at the contact line, 94\% of them took place in the NGCA (Trends and Observations 2020).

Another issue, the recommendation of the special status for the territory, the Special Order of local self-government for some areas of Donetsk and Luhansk regions within the Package of Measures for the Implementation of the Minsk Agreements (Paris "Normandie" 2019) provoked public discussions on the Steinmeier Formula and Minsk Agreements in general (Explainer 2019; Attitudes of Ukrainians 2019). The perspective of local elections in the still-occupied NGCA, amnesty of separatist combatants, and other aspects of the negotiations within the Agreements is deeply rooted in the identification of localness of the population, and it may have an impact on the decisions of IDPs to return to their former places of residence, and the motivation for the NGCA locals to decide on displacement to the government-controlled regions of Ukraine or migration to the Russian Federation.

Thus, the study of localness transformation and the models suggested in the paper may contribute to a better understanding of the sense of belonging to a place under the pressure of migration-invoked aggravations of social and communicative space of a displaced person. The pulses of localness in the situation of forced migration, as suggested further in the model of a ritournelle, for instance, if reflected in the applicable legislation reform, in and out of Ukrainian context, could change the vector of social cohesion restoration towards the registration-bound practices reframing or abolition, and building the reconciliation process in a society with attention to the conflict-affected groups, based not on their migration background, but rather on their localness adaptation attainments and needs. The issues that can be investigated further on this topic and the perspectives of the consequent researches on localness are suggested in the Conclusions section of the article.

The terms and notions have been referred to in this article as follows. Conflicttriggered protracted internal displacement refers to the internal displacement of the population in Ukraine since 2014 (Kälin and Entwisle 2017), due to the annexation of Crimea by the Russian Federation and the consequent armed conflict in the eastern Donbas region of Ukraine. In the Ukrainian context, the term IDPs is further used in the article towards the persons displaced from the NGCA of Donetsk and Luhansk oblasts of Ukraine. The internal displacement from Crimea in 2014 is not accompanied with the armed conflict in the occupied territory and therefore is beyond the scope of the paper. Returnee is thereafter applied to the persons having moved to the government-controlled regions of Ukraine, and then moving back to the former place of residence, despite the armed conflict perils. In the paper, for the purpose of the localness study, IDPs and returnees have been singled out of the 
group of mobile citizens. The complicated residence registration system in Ukraine affects the mobile citizens having changed their place of residence for academic, employment, or personal reasons without adjusting the formal registration. Nevertheless, the scope of the study includes only conflict-affected mobile citizens, in terms of the "ties with their abandoned place of residence, and inclusion of IDPs in communities where they enjoy the right to participate fully in local democracy" (Evaluation 2020, p. 51). Adaptation is used to the state that indicates the inclusion and incorporation of newcomers into the host community as a result of integration (Grzymala-Kazlowska and Phillimore 2017). Double otherness is used in the article to describe the risk of alienation of returnees both from their host community due to refusal or inability to integrate, and from the community of return in the NGCA, due to the previous pro-Ukrainian choice. The otherness of IDPs in Ukraine has been studied by Bulakh (2017), in the contradiction of them being "ours" and "others" at the same time, within the category of "strangers among ours" (Bulakh 2017), and in our paper, the lacuna on returnees is to be filled in. Ritournelle missed as an incomplete refrain of displacement refers to the disrupted adaptation cycle of becoming a local from a newcomer in the community of displacement. It implies that a person alienates from the place of former residence to live in a receiving community and then experiences a secondary alienation from the host community as well. To compare, ritournelle achieved as a complete refrain of displacement means hereto that the cycle of sociocultural adaptation, and "becoming a new local," is complete. Nevertheless, it can be regarded as a form of assimilation that is "not the most preferred and common way of acculturating" (Sam and Berry 2010, p. 479), and can lead to the disappearance of displacement-specific questions from agendas. The right to equal treatment, after Dworkin, refers to equal distribution of opportunities, burdens, and resources; therefore, the right to treatment as an equal implies seeking respect and concern, regardless of the burdens and resources distribution (Dworkin 1978, p. 227). After Pillar 4 "Human security, social cohesion and recovery with a particular focus on Eastern Ukraine" of 2018-2022 Partnership Framework of Government of Ukraine and the United Nations, "there is a strong correlation between social exclusion and insecurity," and "rebuilding of social capital and social ties should promote development of a cohesive society in Ukraine" (The UN Partnership 2017). Thus, intercommunity regulatory aspects imply the mechanisms that enhance and support the sense of belonging and thus social cohesion within a community. The mechanisms include common initiatives, interpersonal reliance, and engagement of newcomers in decision-making, dual targeting in the distribution of benefits to vulnerable groups of both IDPs and locals.

\section{Theoretical background and literature review}

In the article, the situation of internal displacement and the return has been referred to in terms of territorial assemblage, as well as its correlation within the refrain (ritournelle) of chaos, abode, and escape, viewed through Deleuzian interpretation. 
In A Thousand Plateaus (Deleuze and Guattari 1987), the aspects are regarded rather as a single unit than a succession:

Sometimes one goes from chaos to the threshold of a territorial assemblage: directional components, infra-assemblage. Sometimes one organizes the assemblage: dimensional components, intra-assemblage. Sometimes one leaves the territorial assemblage for other assemblages, or for somewhere else entirely: inter-assemblage, components of passage or even escape. And all three at once. Forces of chaos, terrestrial forces, cosmic forces: all of these confront each other and converge in the territorial refrain (Deleuze and Guattari 1987, p. 312).

The philosophical reflections on "hazards of improvisation" (Ibidem) are imminent in a movement decision of a displaced person. In the field of migration studies, they stop sounding abstract and enable an analysis of the territorialization, as well as deterritorializing and reterritorializing, through sociocultural rhythms and their changes. For instance, appreciation of events and transformation of the passive actors into active participants (Yu 2013, p. 205) can be viewed in the context of access to decision-making as one of the key prerequisites for normalization of a displaced person's life and building the level of trust and reliance necessary for adaptation. Furthermore, after Deleuze and Guattari, "There is a territory when the rhythm has expressiveness." (Deleuze and Guattari 1987, p. 315).

The trust and reliance building require a particular focus laid on the equalityrelated issues in the context of individual and community-supported coping mechanisms. For instance, in the Handbook for the Protection of Internally Displaced Persons (2008), the community-based approach implies individuals and communities as equal partners in protection (Handbook 2008, pp. 10-11). In the same document, the access to a durable solution to displacement, among other aspects, implies the right for IDPs "to return to their place of origin, integrate locally at the displacement site, or resettle elsewhere in the country voluntarily, safely and in dignity" (Handbook 2008, p. 34). Therefore, concerning the conflict-inflicted protracted displacement, the situation in Ukraine is to be regarded through integration/return perspective, as well as equality, in the aspects of movement and resettlement. The Handbook suggests equality in terms of "equal access to public services" (Ibidem), thus addressing rather "the right to equal treatment" than "the right to benefits and burdens distribution. The adaptation processes are depicted through dignity-related respect and concern claims satisfaction.

Taking to account the above-mentioned two-dimensional understanding of equality suggested by R. Dworkin, it is necessary to mention that, from the perspective of the right to equal treatment, the distribution of burdens and resources becomes rather problematic in IDPs-related situations. The international legal requirements imply the absence of preferences and dependencies distinguishing the affected group from the other citizens, and in many situations, it clashes with the specific challenges emerging during displacement. Sabates-Wheeler (2019) points out that "The cornerstone of IDP protection is non-discrimination, i.e., equal recognition of IDPs' rights without regard to their displacement" (Sabates-Wheeler 2019). At the same time, the displacement-specific and displacement-intensified disadvantages 
and social contexts, after the researcher, determine the decisions of IDPs to remain, migrate, return, or move onward (Ibidem). Therefore, Sabates-Wheeler claims that there is a need for a better understanding of the role social protection plays in peoples' decision to move (Ibidem).

The international experience of internal displacement investigation includes the aspects relevant to this article. Violation of the rights and victimization of IDPs is a topical issue in the research field. Retrospectively, for instance, Brown and Mansfield (2009) studied equality violations due to the categorization present in the institutional problem-solving instruments. Beneficiary selection and categorization were considered a special issue of protracted displacement and an example of assistancetargeting in the IDP-crises in Sri Lanka, Angola, Bosnia and Herzegovina, where the lines established by both outside donors and agencies, and the governmental institutions, had a great impact on the lives of the recipients and non-recipients of the support. The labels of "an IDP," "a repatriated refugee," etc., were necessary for the affected countries mentioned, for the citizens to get assistance. Therefore, there was formed a gap of misconception between those who left the dangerous areas and registered in other regions, and those who stayed in the problematic area or were not displaced due to various circumstances, or became a returnee (Brown and Mansfield 2009, p. 17). The issue is still actual nowadays, and the IDP status implies not only the opportunity for the specific problems to be resolved systemically on the local level but also to form a source of a long-term dependency of welfare on this image of a victim.

Furthermore, to better understand the situation of displacement and return in Ukraine, it is necessary to refer to other recent internal displacement situations. For instance, in Nigeria, the massive conflict- and natural disasters-related displacement is viewed in the context of legal and social problems, as well as the participation of IDPs in decision-making on relocation, return, and assistance programs (Akume 2015; Oduwole and Fadeyi 2013; Shedrack and Nuarrual 2016). According to the Kampala Convention, the state plays a central role in regulating the displacement situation in Nigeria. There are the factors that can breach the IDPs' trust in the state and reliance on authorities in Nigeria. For instance, the trust was compromised by accidental bombing by state forces of Rann IDPs' camp in 2017. For Round 31 of Nigeria Displacement Report, in 2020, 2,046,604 or 420,072 households were recorded as displaced, and a total of $1,673,862$ persons were identified as returnees (DTM Nigeria 2020; IOM Nigeria 2020). The proportion of returnees is much higher than in Ukraine. Nevertheless, in the Ukrainian context of the conflict-triggered displacement, the returns to the militarily unsafe regions of the NGCA are voluntary, and in Nigeria, for instance, there was exercised a forced return of IDPs to still-unsafe Guzamala in 2018.

Among the Ukraine-specific challenges associated with the situation of extensive and protracted displacement, in the context of Russia-inflicted and supported armed conflict in eastern Ukraine (Donbas) and occupation of the parts of the territory of Ukraine (Crimea), there should be noted some important narrative-based and region-specific issues. Firstly, describing supra-means of military and non-military ways of the Russian Federation towards Ukraine, based on the notorious "Gerasimov Doctrine," Morris (2015) outlines the phases of initial destabilization, deception, 
information operation, and limited military intervention. The possibility of de-centralized insurgency or "frozen conflict," as well as international support of military operations, and assistance to IDPs, after Morris, results in territorial defense-related political objectives and "beyond-limits" war (Morris 2015). In this regard, Ukrainian researchers point out the features of hybrid/network warfare that define the unique context in terms of involved subjects. The latter can be unaware of the final aims for their actions (Bocharnikov and Sveshnikov 2017, pp. 5-6). For instance, while realizing personal choices and decisions, the population of the NGCA and returnees can serve a targeted audience for information operations and deceptions by the Russia-backed separatist movements. At the same time, the hybrid war is not a mere evolution of warfare, but the testing of a new approach to interstate destabilizing (Dodonov et al. 2017; Levchenko 2017) and massive migration consequences. The related investigations also lay the focus on social cohesion in conflict-affected societies, as well as interactions between IDPs and host communities (Bulakh 2017; Smal 2016), and identity issues and reintegration scenarios perception by population (Haran et al. 2019; Toward 2020; Ukrainians Perceptions 2020).

Secondly, the split in the politically loaded opinions towards the military expansion of the Russian Federation can be traced to the conflict in South Ossetia in 2008, when the Party of Regions in Ukraine took the Russian side in the Caucasus crisis (Pietnoczka 2015, p. 133). The party got strongly associated with Donbas due to Victor Yanukovych, and his pro-Russian position was further interpolated onto the IDPs from Eastern Ukraine. This type of narrative is also greatly influenced by the informational distortions and propaganda in Russian mass-media in the NGCA. Among the hybrid war means of the kind, there can be named, for instance, space and time attribution of facts (when an event having taken place in $\mathrm{A}$ is represented as that taking place in B) and other falsifications aimed at opinion-molding (Kiklewicz 2015, pp. 191-193). The intention to show the Ukrainian events as chaotic and intolerant ones is realized in the Russian mass-media via persuasion and manipulative techniques based on the ideology-based presuppositions (Kiklewicz 2015, p. 189). Another narrative-based aspect of the hybrid war in the context of internal displacement in Ukraine was investigated by van Metre et al. (2017). The researcher suggested that the hybrid narrative of a "civil war" rather than a "Russia-instigated war," that it is, leads to the marginalization of IDPs when they are evaluated as separatists and anti-Ukrainian position defenders (Van Metre et al. 2017, p. 10). It can have a further negative impact on the social cohesion in the communities.

As for the normative aspect, there should be mentioned that on August 30, 2019, in the Resolution of the Cabinet of Ministers of Ukraine (CMU) No. 788-2019-p, there were put into effect the important amendments to the CMU Resolution No. 637-2014-p "On social benefits for internally displaced persons." The registration issue was partially substituted with IDP status recognition: "in paragraph five the words "registered as IDPs" to be changed with "being IDPs" (The CMU Resolution 2019). The change is important in the context of the right to be treated as an equal, just assuming the specific situation, without isolation from the other groups having specific needs in a host community.

The discriminatory limitations are still connected with the returnee status. In particular, the regulations of the Resolution contain information on the controlling 
function of some institutions, such as the State Customs Service, the Ministry of Internal Affairs, the Security Service of Ukraine (SSU), the National Police, the State Migration Service, and the Ministry of Finance, as well as the local authorities. The institutions are supposed to report to the Pension Fund of Ukraine "that there is the reasonable belief to consider the person having returned to the abandoned former place of residence" (The CMU Resolution 2014), with a further suspension of the IDP-related payments. The aspects of the above-mentioned contradiction breaching the equality of treatment claim can be traced in several cases. For instance, there is an exemplary case on the pension having been suspended due to unsatisfactory physical identification of the IDP (in Severodonetsk, Donetsk region), as the person was absent from home during the audit by the social service. The Supreme Court of Ukraine's decision was to satisfy the IDP's claim (Decision 2018). One more important pre-conflict and not IDP-related case (Case 2013) referred to a registration-bound suspension of the payments: The European Court of Human Rights sustained the claim that life-long pension should not be one-way suspended based on territorial circumstances or change of the place of residence, and the situation is correlated with the nowadays returnees-related practice of the Pension Fund claims to the authorities, in order "to prove or disclose the information on the person having returned to the abandoned former place of residence" (The CMU Resolution 2014), thus violating the right to treatment as an equal, if compared to the persons entitled to the same life-long pension payments in the government-controlled area of Ukraine.

\section{Results}

Taking into account the deterritorializing and reterritorializing tendencies associated with internal displacement and reflected in the data of the relevant reports and surveys on Ukraine, the idea of localness can be regarded through the correlation between the sense of belonging to a community and the options of an abode lost through displacement, discovered by newcomers in a host community, or rediscovered upon voluntary return to the former community (Fig. 1).

The localness upon conflict-triggered displacement is referred to as a liquid localness corresponding with the notion of a chaotic gray point, as suggested by Paul Klee (Deleuze and Guattari 1987, p. 312). There is a point when the gray point "has jumped from one state to another, and no longer represents chaos but the abode or home" (Ibidem). Intercommunity regulatory aspects including otherness, participation, and equality issues harmonization promote the leap to the ritournelle achieved. This dimension of localness does not imply assimilation in the common space but rather indicates the shaped decision to adapt to the community as a local, thus sharing both burdens and benefits with other members of the community, rather than being a victim or a bystander. The ritournelle missed indicates the state of an escape from adaptation. According to the survey data, the financial and emotional factors play a leading role in shaping this decision. In Ukraine, the decision appears also to be age-specific, as the returnees are mostly persons over 60 . Nevertheless, in 


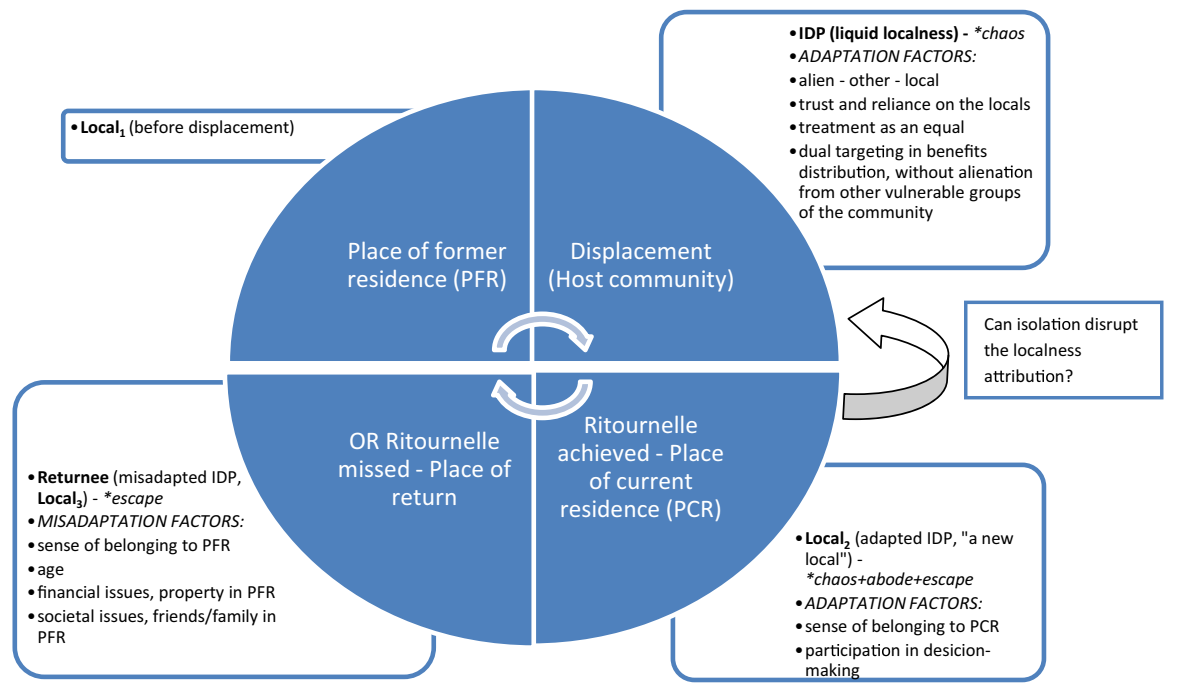

Fig. 1 Ritournelle of displacement: adaptation and misadaptation factors

the context of the refrain, the decision for $3 \%$ returnees is not a final one (National 2019 b, p. 56) and can be regarded as a pause mode before the next cycle of displacement.

Thus, on the one hand, making new assemblages via reliance and trust-building implies the refrain-like interchanges between chaos and abode, integration, and return. The final reintegration and its place depend on otherness issues, belonging, and adaptation mechanisms. On the other hand, the current approach to assistance distribution can also be estimated as discreetly instrumental, as the "value" of IDPs for the community projects and purposes lies beyond the real capacities and resources of the newcomers, thus putting the artificial limitations for the implementation of the durable solutions on both individual and community-based levels. Thus, the right to treatment as an equal can be realized through dual targeting in benefits distribution that makes it possible to avoid victimization and further alienation of IDPs.

As for the refrains of internal displacement (IDP ritournelle) in Ukraine, the inter-assemblages that could enable the affected group (both IDPs and returnees) "to pass from territorial to other [social] assemblages" (Deleuze and Guattari 1987, p. 325) are still problematic and narrative-dependent. Formulating the durable solutions on reintegration, and social cohesion enhancement, requires additional empirical research of returnees' attitudes and the consequences of their voluntary return to the potentially unsafe territory, as well as the alternative for them to become allies or just another factious group at the stage of conflict regulation. The investigation of the sense of belonging to a community, the ways of its forming and disintegration in the mythologeme-laden context of the hybrid war, can promote a better understanding of the role of localness as an 
identity vector, especially concerning the issues of a current/former communities' space specific for internal displacement.

\section{Discussion}

To trace the ritournelle tendencies in Ukraine, it is useful to refer to the data on the returnees provided in the NMS Reports (National 2018, 2019a, b, c) that gain particular importance in the context of the current contradictory reintegration attempts made by the Ukrainian authorities. It is difficult to define an exact pool of returnees in Ukraine. As of January 2020, the estimated number of 670,000 of the registered IDPs is believed to live permanently in the NGCA (Humanitarian Needs 2020, p. 66). According to the data of Round 15, 2019, the group of returnees to the NGCA is age-specific, and the average age of the surveyed returnees is 59.4 years old. The majority of the group is 60 years or older, and $67 \%$ of returnees' households are comprised of persons aged over sixty only (National 2019c, p. 49). Moreover, 47\% of returnee households are composed of one person (National 2019c, p. 48) and, the indicator overlapping with the age statistics of the group, may indicate a particular need for support from the local community and/ or authorities. The vulnerability of returnees is also reflected in the infographic of The National Human Rights Strategy Assessment (2020). On the one hand, in the diagram depicting structural, result, and process indicators (The National 2020, p. 5), there can be traced a significant, more than three-time, disparity in human rights protection of IDPs and residents of the temporarily occupied territories of Ukraine. On the other hand, while there is a $52 \%$ progress in the protection of IDPs, 2016-2019, the progress protection of the rights of persons living in the settlements of Donetsk and Luhansk regions where state authorities temporarily do not perform or partially perform their duties does not exceed $14 \%$ (The National 2020, p. 4), and in some registration-of-residence aspects, such as pensions and social benefits payment, births and deaths registration procedures, there is a negative trend in ensuring the rights of the NGCA residents (The National 2020 , p. 7). The understanding of the conditions is vital, as we should assume the motivation of the returnees, for they change a more or less rights-protected status of an IDP for an aggravated situation of a resident of the temporarily occupied territories. Therefore, several issues that should be taken to account as follows: (1) a reflexive aspect of self-evaluation of the displacement situation by displaced persons, for instance, perception of the displacement as a temporary or permanent situation; (2) an aspect of social immersing, such as a sense of belonging and a level of interdependence of the members of a community; and (3) an adaptive reasoning aspect, including the practices ensuring equality and participation of the displaced persons in decision-making on the community and state levels, for their migration-specific needs to be heard in the discourses.

To what extent does perception of the displacement as temporary or permanent influence the decision of an IDP to return or integrate? 89\% of IDPs in Ukraine indicate that housing is the condition for integration in the local community; other conditions include regular income (78\%), family and friends at the same 
place (45\%), and access to public services (42\%) (National 2019c, p. 42). The aspects appear to be the key in defining the displacement as temporary or permanent. For instance, private property in the NGCA and absence of necessity to rent $(94 \%)$ and family-related issues (19\%) were pointed out as the reasons for the return (National 2019c, p. 53). 54\% of returnees did not visit governmentcontrolled territory (Ibidem), and 3\% stated that they had plans to move to the government-controlled area (National 2019c, p. 56). At the same time, the polarization of the IDP group in the context of return is quite significant. To compare, since June 2018, based on NMS information, there was fixed emergence of the new variant of an answer to the question on the reasons for not to visit the NGCA after displacement: "no need for visiting" (increasing to 37\% in September 2018 and 44\% in March 2019, then dropping to 33\% in the survey data as of June 2019 (National 2019b, p. 39). The answer was not registered in the previous rounds of interviews.

The restrictions aimed at mitigating the spread of coronavirus have been introduced since March 11, 2020, and affected the mobility of the group. For instance, according to the Returnee Express Survey conducted via phone, based on the IOM National Monitoring System sample, those who returned to the NGCA are in the primary concern group (Impact of COVID-19 2020). The majority (88\%) of the surveyed returnees switched to the financial assistance (pensions) provided by de facto authorities in the occupied territories, during the lockdown (Ibidem). Thus, the quarantine furthermore impeded interrelations with the government-controlled areas and made the evaluation of displacement as temporary or permanent unpredictable.

What is the role of reliance on locals, family, and authorities in making the choice to return? To what extent does the sense of belonging to the place, and nostalgia, influence the individual coping mechanisms during internal displacement? The analysis of the pre-quarantine NMS Rounds data allows tracing the shift in evaluation of the sense of belonging to the community in former/current place of residence, as correlated with support of the local community being named among the conditions for integration. The frequency of IDPs' reliance on locals for everyday favors is another indicator of interpersonal cohesion in the IDP-recipient community. In 2019, a "very strong" and "strong" sense of belonging to the community in the current place of residence was reported by $28 \%$ of the informants, which correlates with 36-41\% having a "very strong" and "strong" level of the sense of belonging to the former place of residence (National 2019b, p. 47, c, p. 44). Furthermore, $36 \%$ of IDP informants expressed the intention not to return even after the end of the conflict (National 2019b, p. 36, c, p. 34); to be compared with $88 \%$ of the informants having reported integration into their current community, in 2019 (National 2019c, p. 40). There is a distinct correlation between the geographical distribution of IDPs in the government-controlled area and the intention to return to the former place of residence. Among 2018-2019 NMS Reports, there remained stable the tendency that the intention not to move from the current place of residence was higher in the IDPs residing farther away from the line of contact with the NGCA (52\%, in comparison to 27\%, correspondently, in 2018 (National 2018, p. 35); 57-58\% and 24-28\% - in 2019 (National 2019b, p. 37, c, p. 34). In the last pre-quarantine NMS Report, there was mentioned in the conclusion on the integration of IDPs to their 
local communities that 'the data demonstrated that IDPs' self-assessment of their integration in the local community correlated the most with a frequency of reliance on locals for everyday favors, as well as a sense of belonging to people in their current place of residence" (National 2019c, p. 42). The forced isolation arising from the needs of the pandemic-triggered situation is a challenge for the group; the lockdown can lead to partial deterioration of social surroundings, and further affect localness attribution, level of trust, and sense of belonging to the current place of residence. Thus, the main focus for further investigation may be laid on the problem of the possibility of "anticlockwise moves" in a ritournelle of localness, and whether, for instance, under the pressure of the isolation from the community, the adapted state of a ritournelle achieved can rewind to liquid localness (Fig. 1), due to the social capital disintegration.

Is equality of IDPs in a host community achievable in the context of de facto limited access to decision-making, and difficulties in benefits distribution? Though, in general, the sense of belonging to the former community and place of residence is high (as for the surveys data 2018-2019), the nostalgic reflections of the pre-conflict life are likely to become mythologeme-based, as the polarization of the intentions described above leads to inevitable changes in the communities having been disrupted since 2014 into IDPs, returnees, and those who never left their place of residence in the NGCA during the conflict. The communities in the NGCA are also nonhomogeneous as for the approaches and attitudes towards Ukraine, the self-proclaimed republics, and the Russian Federation. This can be illustrated based on the profile of the group of supporters of reintegration and the special status of Donbas, from the NGCA sample of SCORE for eastern Ukraine survey (Toward 2020). The participants from Donetsk and Luhansk oblast settlements of the NGCA selfdefine as "political agnostics," and the return of the occupied regions to Ukraine is regarded by some of them as a practical decision (Toward 2020, p. 51). The nonhomogeneity of the NGCA population's vision of future resolution of the conflict can be traced through the Belonging and Identity dimension of the group profile. The most contradictory data describe that $1.9 \%$ of persons with the identity of citizens of the self-proclaimed republics are ready to support the reintegration of the NGCA to Ukraine, with a special status of Donbas; at the same time, $1.2 \%$ of the survey respondents from the NGCA, with Ukrainian identity, and $0.2 \%$ with the identity of citizens of Ukraine, expressed "uncompromising support for separation" (Toward 2020, p. 52). Furthermore, as for the Political Orientations and Attitudes dimension of the group profile, $1.3 \%$ of the separation supporters share the perception that the self-proclaimed republics "cannot exist without Ukraine," and 1.7\% of them perceive that the NGCA residents "are willing to be part of Ukraine" (Ibidem); to compare with the perception of $5.2 \%$ of reintegration-supporters that the self-proclaimed republics' residents "are willing to be part of Russia" (Ibidem).

As for the government-controlled territory of Ukraine, the equality issue touches upon, firstly, IDPs' participation in decision-making in host communities, and it has become a serious challenge. For instance, to avoid reverse discrimination, the IDPspecific problems are to be addressed with the focus on the impact of the resource distribution on the interpersonal relations between IDPs and the host communities, the main goal being to realize and strengthen the capacities of both communicative 
actors. The international practice of problem-solving of the kind was implemented, for example, in Sri Lanka in 2009, where only IDPs received international assistance, and the host community had concerns about being neglected and economically left out (Brown and Mansfield 2009, p. 16). The durable solution was to address poverty in the host communities, to ensure that all persons in need are supported appropriately. This situation, described in the Listening Project, correlates with similar patterns in the modern Ukrainian context. For instance, as for the perception of people from Donbas and Crimea by the local population at host communities in 2017, government assistance to IDPs caused animosity of "locals who themselves are experiencing significant economic dislocations" (Van Metre et al. 2017, p. 7).

In Ukraine, since 2019, there has been significant progress in protecting the rights of IDPs and promoting treatment as an equal. Therefore, in some cases, the situation of disrupted adaptation was prevented. For instance, IDPs were enabled access to decision-making in the host communities by participation in local elections (Evaluation 2020), for the first time since the beginning of the war, and thus, both the sense of belonging to the current place of residence and localness of the ritournelle achieved in general became more realizable for IDPs.

On the one hand, the "integration vs. return" issue is region-specific as it depends on the background and consequences of IDPs' integration into the host communities, as well as their estimation of the displacement as a temporary or a permanent one. In the last pre-quarantine NMS Report, in 2019, 6-11\% of the respondents self-assessed their situation as an absence of integration to their local community of displacement (National 2019c, p. 41), and the group might be prone to a disrupted adaptation and return. On the other hand, the integration/isolation/self-isolation issues are based on otherness polarization in communities and the complex of intercommunity regulatory aspects incorporating both interpersonal reliance and nostalgia for the pre-conflict existence. Thus, the return (im)probability in the situation of the current forced isolation crisis during the pandemic makes it possible to further reformulate the localness transformation problem to a trivial but important question: "Where would you prefer to spend the lockdown, in the current place of residence or the former one?", as an indicator of the sense of belonging and preferable social surrounding perceived by a displaced person.

\section{Conclusions}

Taking to account the international practice of internal displacement regulation, especially in the situation of armed combat in the regions left by IDPs, the attention to returnees' problems and study of the reasons and consequences of the ritournelle missed can be prospectively productive. Inaccessibility of the reliable data on the population of occupied regions makes the sample of returnees in the internal displacement surveys definitely valuable. In Ukraine, the pool of returnees has made it possible to monitor the needs and attitudes in the NGCA even in the situation of the quarantine when the information blockade worsened. 
The analysis of the survey data makes it possible to single out the possible dynamic localness-related tensions. Among them, there are the misadaptation triggers, such as dependence on migration-related benefits and programs, safety issues, and discrimination arising from the residence registration system limitations.

The impact of disrupted adaptation on post-conflict regulation strategies in Ukraine can be prognosed based on the latest data on attitudes towards the NGCA residents, regional cooperation, responsibility, and state policies regarding the NGCA, as provided in Ukrainians perception of the Human Rights Challenges Triggered by the Conflict in the East of Ukraine (2020). In the situation of a disrupted adaptation and return to the occupied territories, returnees appear in the same situation as the citizens of the NGCA, regardless of the motives preceding the return and attitudes towards the state. For instance, in 2020, the average of $11.2 \%$ of the respondents all over Ukraine considered that "If people chose to stay in the NonGovernment-Controlled Territories, Ukraine should not provide them with any support," and 3.7\% chose the variant "I do not care, I don't think about people living in the Non-Government-Controlled Territories" (Ukrainians Perceptions 2020, p. 1). The interregional cooperation biases reflect the factious polarization of the society due to the conflict, and the mutual alienation of the parties, however, nonhomogeneous they could be. At the same time, 46.8-67.6\% of respondents in different regions of Ukraine support the policy of the renewal of connections with people living in the NGCA, and $54.7 \%$ of respondents consider that the NGCA residents are "victims of the conflict that require comprehensive support" (Ibidem). The victimization can be alienating and maladaptive as well. It is another side of the cooperation biases to be overcome through the ritournelle achieved. For instance, as for the evaluation of possible future criminal responsibility of the NGCA residents, $6.6 \%$ of the respondents from all regions of Ukraine support the position that "Everyone who stayed in the Non-Government-Controlled Territories cooperates with the authorities of the so-called LPR/DPR" (Ukrainians Perceptions 2020, p. 2), and the returnees choosing to go back to their homes in the NGCA take the risk of such stigmatization as well.

As for the recommendations for the policies to be incorporated into existing state practices, on the one hand, it may be timely for this stage of conflict to provide the projects on civic literacy and human rights awareness aimed at overcoming both victimization and exoticization of the residents of the occupied regions, and returnees among them. On the other hand, the policies aimed at overcoming the residence registration system frames, to follow the recent state practice of giving IDPs access to local elections, regardless of their place of registration, might help to shift the accent from the importance of the spatial indicator of residence to the equality and responsibility intrinsic for actual citizenship as it is.

Thus, the approach to localness as a dynamic project of a person can be productive in the field of migration studies. For instance, both the ritournelle missed and ritournelle achieved represent the cycle of localness adjustments and therefore suggest a reflective perspective of integration and reintegration. Participation in decision-making, aside from financial and emotional aspects of adaptation, is an important regulatory aspect that promotes a sense of belonging to the community of 
displacement and therefore can serve as an indicator of social cohesion in terms of localness without assimilation.

There is still a set of questions to be answered in future studies of the choice between return and integration, in and out of the Ukrainian situation of conflict-triggered displacement. Among the questions, the following ones can be suggested as discussable ones in the field of migration studies: What is the possible effect of the ritournelle missed on policies regulating internal displacement? Can the results be applied to other situations of migration and return, for instance, return refugees? For Ukraine, the reliable data on migration of the population from the NGCA to the Russian Federation, as well as the situation on return refugees from the country, are mostly inaccessible. Other questions for further investigations sound as follows: Can the intention of IDPs to return to the occupied and conflict-affected regions with low social stability and safety level be regarded as the indicator of social cohesion problems, such as widening the gap between the factious parts of a country? What are the possible risks at the stage of the post-conflict reintegration associated with the group of returnees and their failed integration experience?

Therefore, the dynamic approach to localness and otherness has the potential to cover not only the topic of internal displacement but also the wider scope of migration issues concerning primary and secondary migration.

Funding Not applicable.

\section{Compliance with ethical standards}

Conflict of interest The authors declare that they have no conflicts of interest.

Data availability All data analysed are included in the paper.

\section{References}

A Review of Empirical Surveys of Asylum Related Migrants (2018) Report. European Asylum Support Office. https://www.easo.europa.eu/sites/default/files/easo-review-surveys-1-2.pdf. accessed 17 Nov 2020

Akume A (2015) the question of internally displaced persons (IDPs) in Nigeria: a reflection on present realities. J Third World Stud 32(1):221-244. https://doi.org/10.2307/45195119

Bocharnikov V, Sveshnikov S (2017) Pogliady na kharakter suchasnykh voennykh konfliktov [Views on the nature of modern military conflicts]. Natsionalna bezpeka i oborona 1:3-8

Brown D, Mansfield K (2009) Listening to the experiences of the long-term displaced. Forced Migr Rev $33: 15-17$

Bulakh T (2017) 'Strangers among ours': state and civil responses to the phenomenon of internal displacement in Ukraine migration and the Ukraine crisis. A two-country perspective. E-International Relations Publishing, Bristol, pp 49-61

Case of Pichkur v. Ukraine (2013) Application No. 10441/06. Judgment of European Court of Human Rights. http://hudoc.echr.coe.int/rus?i=001-127810. accessed 13 Aug 2020

Decision in the exemplary case of the suspension of pension to an internally displaced person (2018) Case No. 805/402/18. Proceeding No. Pz/9901/20/18. https://www.refworld.org/cases,UKR_ SC,5bd1df444.html. accessed 13 Aug 2020

Deleuze G, Guattari F (1987) A Thousand Plateaus: Capitalism and Schizophrenia. Continuum, London, New York 
Digidiki V, Bhabha J (2019) Returning Home: The reintegration challenges facing child and youth returnees from Libya to Nigeria. https://cdn1.sph.harvard.edu/wp-content/uploads/sites/2464/2019/11/ Harvard-FXB-Center-Returning-Home-FINAL.pdf. accessed 15 Aug 2020

Dodonov R, Kovalskyi H, Dodonova V, Kolinko M (2017) Polemological paradigm of hybrid war research. Philos Cosmol 19:97-109

DTM Nigeria Displacement Report (2020) IOM. https://cutt.ly/9d46WUz. accessed 15 Aug 2020

Dworkin R (1978) Taking rights seriously (with a reply to critics). Harvard University Press, Cambridge

Etikan I, Musa SA, Alkassim RS (2016) Comparison of convenience sampling and purposive sampling. Am J Theor Appl Stat 5(1):1-4

Evaluation of Implementation of the National Human Rights Strategy (2020) UNDP. https://www. ua.undp.org/content/ukraine/en/home/library/democratic_governance/the-national-human-right s-strategy-assessment.html. accessed 11 Aug 2020

Grzymala-Kazlowska A, Phillimore J (2017) Introduction: Rethinking integration. New perspectives on adaptation and settlement in the era of super-diversity. J Ethn Migr Stud 44:179-196. https://doi. org/10.1080/1369183X.2017.1341706

Handbook for the Protection of Internally Displaced Persons (2008) UNHCR. https://www.unhcr .org/4c2355229.pdf. accessed 13 Aug 2020

Haran O, Yakovlyev M, Zolkina M (2019) Identity, war, andpeace: public attitudes in the Ukraine-controlled Donbas. Eurasian Geogr Econ 60:684-708. https://doi.org/10.1080/15387216.2019.1667845

Hillier-Smith B (2020) Doing and allowing harm to refugees. J Ethics Soc Philos 18(3):298-321. https:// doi.org/10.26556/jesp.v18i3.955

Humanitarian Needs Overview. Ukraine (2020) OCHA. https://reliefweb.int/sites/reliefweb.int/files/resou rces/Ukraine \%20Humanitarian $\% 20$ Needs $\% 20$ Overview $\% 202020 \% 20 \%$ 28Issued $\% 20 J a n u a r y \% 20$ 2020\%29.pdf. accessed 17 Aug 2020

Impact of COVID-19 Disease and Related Restrictions on Small Business and Vulnerable Populations in Eastern Conflict Area (GCA and NGCA). IOM Ukraine Express Surveys Report (2020) https://displ acement.iom.int/system/tdf/reports/IOM_Ukraine_Express_Surveys_Report_A4.pdf?file=1\&type= node\&id=8273. accessed 11 Aug 2020

IOM Bi-monthly Report (2020) https://iom.org.ua/sites/default/files/iom_ukraine_assistance_report_ july_2020_eng.pdf. accessed 15 Aug 2020

IOM Nigeria Displacement Tracking Matrix Round XIV (2017) IOM. https://cutt.ly/4d46DAP. accessed 15 Aug 2020

Kälin W, Entwisle H (2017) Breaking the impasse: Reducing protracted internal displacement as a collective outcome - Case Study: Ukraine. United Nations Office for Coordination of Humanitarian Affairs (OCHA). https://reliefweb.int/report/ukraine/breaking-impasse-reducing-protracted-inter nal-displacement-collective-outcome-case/. accessed 26 Jan 2020

Kiklewicz A (2015) The Political Propaganda in the modern Russian mass media. Przegląd Wschodnioeuropejski 1(2):179-199

Levchenko O (2017) Evoliutsia hibrydnoi viiny Rosiiskoi Federatsii proty Ukrainy [Evolution of the hybrid war of the Russian Federation against Ukraine]. Natsionalna bezpeka i oborona 2:11-16

Morris V (2015) Grading Gerasimov: Evaluating Russian Non-linear War through Modern Chinese Doctrine. Small Wars Journal. https://smallwarsjournal.com/jrnl/art/grading-gerasimov-evaluating-russi an-nonlinear-war-through-modern-chinese-doctrine. accessed 17 Aug 2020.

Na Donbasi budut chotyry novi tochky rozvedennia - Shtab [In the Donbas, there are Four new Points of Disengagement - The Headquarters] (2020) Radio Svoboda News. https://www.radiosvoboda.org/a/ news-rozvedennia-viysk/30930067.html. accessed 1 Dec 2020

National Monitoring System Report on the Situation of Internally Displaced Persons (2018) Round 12. IOM in Ukraine. http://iom.org.ua/sites/default/files/nms_round_12_eng_screen.pdf. accessed 19 Jan 2020.

National Monitoring System Report on the Situation of Internally Displaced Persons (2019a) Round 13. IOM in Ukraine. http://iom.org.ua/sites/default/files/nms_round_13_eng.pdf. accessed 19 Jan 2020

National Monitoring System Report on the Situation of Internally Displaced Persons (2019b). Round 14. IOM in Ukraine. http://iom.org.ua/sites/default/files/nms_round_14_eng_web.pdf. accessed 13 Aug 2020.

National Monitoring System Report on the Situation of Internally Displaced Persons (2019c) Round 15. IOM in Ukraine. https://iom.org.ua/sites/default/files/nms_round_15_eng_screen.pdf. accessed 11 Aug 2020 
Oduwole TA, Fadeyi AO (2013) Issues of refugees and displaced persons in Nigeria. J Sociol Res. https:// doi.org/10.5296/jsr.v4i1.3156

Paris "Normandie" summit (2019) Elysee. https://www.elysee.fr/emmanuel-macron/2019/12/09/paris -normandie-summit.en. accessed 3 Dec 2020

Pietnoczka P (2015) Ukraińskie ugrupowania parlamentarne wobec konfliktu gruzińsko-osetyjskorosyjskiego z sierpnia 2008 roku [Ukrainian Parliamentary Groupings in the Context of the Georgian-Ossetian-Russian Conflict of August 2008]. Przegląd Wschodnioeuropejski 1(2):129-141

Protecting Internally Displaced Persons: A Manual for Law and Policymakers (2008). Brookings Institution - University of Bern. UNHCR. https://www.unhcr.org/50f955599.pdf. accessed 13 Aug 2020

Report on a Reintegration Sustainability Survey among Voluntary Returnees from Finland (2019) IOM. https://migri.fi/documents/5202425/0/2019-10-29+IOM+Finland_Monitoring+Report_Auda. pdf/4e072ae6-0bbf-4014-3079-3386efe4a086/2019-10-29+IOM+Finland_Monitoring+Report_ Auda.pdf. accessed 15 Aug 2020

Sabates-Wheeler R (2019) Mapping differential vulnerabilities and rights: 'opening' access to social protection for forcibly displaced populations. Comp Migr Stud. https://doi.org/10.1186/s4087 8-019-0142-6

Sam DL, Berry JW (2010) Acculturation: when individuals and groups of different cultural background meet. Perspect Psychol Sci 5:472-481. https://doi.org/10.1177/1745691610373075

Shedrack E, Nuarrual Hilal MdD (2016) Legal issues and prospects in the protection and assistance of internally displaced persons (IDPs). Nigeria J Law Policy Glob 49:108-116

Smal V, Poznyak O (2016) Internally displaced persons: social and economic integration in hosting communities (based on materials provided by Vinnytsia Oblast, Zaporizhia Oblast, Ivano-Frankivsk Oblast, and Poltava Oblast). PLEDDG Project. http://pleddg.org.ua/wp-content/uploads/2016/10/ IDP-REPORT_V.Smal_ENG.pdf accessed 17 Aug 2020

Sulaiman-Hill CM, Thompson SC (2011) Sampling challenges in a study examining refugee resettlement. BMC Int Health Hum Rights 11:2. https://doi.org/10.1186/1472-698X-11-2

The CMU Resolution (2014) Pro zdiisnennia sotsialnyh vyplat vnutrishnio peremishchennym ocobam [On social benefits for internally displaced persons] No. 637 of November 5, 2014. The Cabinet of Ministers of Ukraine: Kyiv, Ukraine. https://zakon.rada.gov.ua/laws/show/637-2014-\%D0\%BF. accessed 13 Aug 2020

The CMU Resolution (2019) Pro vnesennia zmin do deiakyh postanov Kabinetu Ministriv Ukraiiny [On amendments to some Resolutions of the Cabinet of Ministers of Ukraine] No. 788 of August 21, 2019. The Cabinet of Ministers of Ukraine: Kyiv, Ukraine. https://zakon.rada.gov.ua/laws/show/7882019-\%D0\%BF\#n25. accessed 13 Aug 2020

The National Human Rights Strategy Assessment (2016-2019) (2020) UNDP. Infographic. https://www. ua.undp.org/content/ukraine/en/home/library/democratic_governance/the-national-human-right s-strategy-assessment.html.InfoHRStrategyEng.pdf. accessed 3 Dec 2020

The UN Partnership Framework for 2018-2022 (2017) The United Nations Country Team (UNCT) in Ukraine. https://ukraine.un.org/sites/default/files/2020-06/UNPF-document-eng.pdf. accessed 3 Dec 2020

The White Paper on the Domicile Registration System in Ukraine. Proposed Reform Paths for the Government (2020) UNDP. https://www.ua.undp.org/content/ukraine/en/home/library/democratic _governance/white-paper-domicile-registration-system-in-Ukraine.html. accessed 11 Aug 2020

Toward a Common Future: Voices from both Sides of the "Contact Line" (2020) USAID. SEED. https ://www.ua.undp.org/content/ukraine/en/home/library/recovery-and-peacebuilding/SCORE-repor t-toward-a-common-future.html. accessed 11 Aug 2020

Trends and Observations (2020) OSCE. Special Monitoring Mission to Ukraine, July-September 2020. https://www.osce.org/files/f/documents/3/a/467739.pdf. accessed 1 Dec 2020

Ukraine: Protection Cluster Factsheet - September 2019 (2019) UNHCR. https://reliefweb.int/report/ ukraine/ukraine-protection-cluster-factsheet-september-2019-enruuk. accessed 17 Nov 2020

Ukrainians Perceptions of the Human Rights Challenges Triggered by the Conflict in the East of Ukraine (2020) UNDP. https://www.ua.undp.org/content/ukraine/en/home/library/recovery-and-peacebuild ing/results-of-the-omnibus-polling.html. accessed 11 Aug 2020.

Van Metre L, Steiner SE, Haring M (2017) Ukraine's internally displaced persons hold a key to peace. Atlantic Council. https://www.atlanticcouncil.org/in-depth-research-reports/issue-brief/ukraine-sinternally-displaced-persons-hold-a-key-to-peace/. accessed 13 Aug 2020

Yu J (2013) The use of Deleuze's theory of assemblage for process-oriented methodology. Historische Sozialforschung 38(2):197-217 